\title{
Bahaya Disintegrasi Bangsa Akibat Otonomi Daerah Pada Masa Mataram Islam
}

\section{Sambung Widodo}

Keywords: disintegration, politics, java, kingdom, power structure

\section{How to Cite:}

Widodo, S. (2003). Bahaya Disintegrasi Bangsa Akibat Otonomi Daerah Pada Masa Mataram Islam. Berkala Arkeologi, 23(1), 96-101. https://doi.org/10.30883/jba.v23i1.864

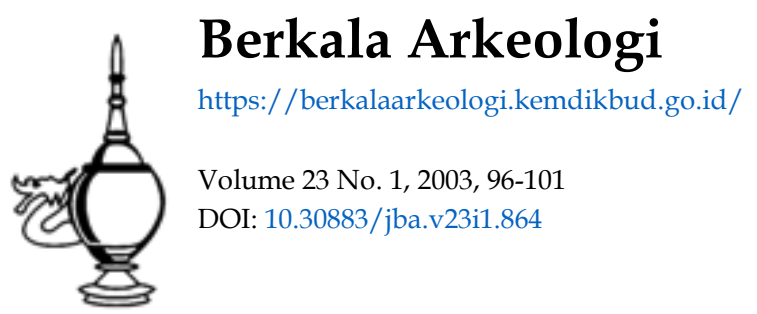

\section{c) (i) (2)}

This work is licensed under a Creative Commons Attribution-NonCommercial-ShareAlike 4.0 International License. 


\title{
BAHAYA DISINTEGRASI BANGSA \\ AKIBAT OTONOMI DAERAH PADA MASA MATARAM ISLAM ${ }^{*}$
}

\author{
Sambung Widodo
}

$\mathbf{P}$ endahuluan

Esensi otonomi daerah pada intinya adalah memberikan kesempatan daerah dengan segala potensi dan sumberdayanya untuk dioptimalkan guna kemajuan dan kemandirian daerahnya. Posisi ini harus didukung kesiapan mengurus dirinya sendiri. Isu tentang alternatif strategi untuk mengembangkan pemerintah yang efesien, tanggap dan akuntabel menjadi dorongan yang kuat untuk segera dilakukan. Salah satu strategi yang penting diperhatikan disini adalah profesionalisasi birokrasi publik. Profesionalisasi diharapkan dapat meningkatkan motivasi dan kemajuan birokrasi dalam memberikan pelayanan publik melalui peningkatan keahlian dan penghargaan intrinsik terhadap para pejabat birokrasi. Lebih dari itu, profesionalisasi birokrasi dapat mendorong lahirnya etika profesi yang dapat menjadi tuntunan bagi para birokrat dalam memecahkan masalah-masalah publik yang amat delematis.

Pengembangan profesi birokrasi menjadi semakin strategis peranannya dalam reformasi administrasi karena birokrasi pemerintah memiliki peranan penting dalam kegiatan pemerintahan dan pembangunan. Sejauh ini peranan birokrasi dalam pembuatan kebijakan publik tetap sangat besar dan dominan. Dalam kondisi dimana kontrol politik yang ada kurang efektif maka pengembangan nilai-nilai dan norma profesi diharapkan dapat mengganti peranan kontrol politik dalam memberi qudance kepada mereka dalam pengambilan keputusan, sehingga keputusan dan tindakan mereka sesuai dengan nilai dan aplikasi yang berkembang dalam masyarakat. Unsur pokok yang terkandung dalam otonomi akan lebih mengarah bagaimana menangkap perubahan lingkungan yang dinamis. Fungsi pemberdayaan SDM secara optimal sebagai pelaku utama perubahan. Telah disebutkan SDM mempunyai kemampuan untuk menghasilkan keunggulan kompetitif yang tidak dimiliki faktor-faktor lain seperti inovasi, kecepatan merespon, fleksibelitas dan kemauan serta kemampuan untuk belajar secara kontinyu. Pengembangan dan pemanfaatan bakat potensi SDM diharapkan akan menghasilkan keunggulan kompetitif Birokrasi dapat mengarahkan dan memanfaatkan bakat potensi melalui pemberdayaan organisasi.

Dengan adanya otonomi daerah ini ditujukan untuk mengembangkan kemampuan pembelajaran yang kontinyu, karena dinamisasi perubahan lingkungan semakin menuntut kemampuan intelektual untuk menghasilkan pengetahuan (Handoko,

Pernah disampaikan pada Evaluasi Hasil Penelitian Arkeologi 2000, di Bedugul, Bali tgl. 14 - 17 Juli 2000 
1996.hal.8). Salah satu strategi adanya otonomi suatu daerah ialah untuk menciptakan kondisi kerja yang demokratis dan mendorong kreatifitas suatu daerah. Tujuan dan otonomi daerah ini adalah untuk memberikan kesempatan dan kondisi yang mendorong proses pemelajaran, daya kreatifitas dan inovasi, serta keberanian untuk mengambil keputusan dan mencapai hasil yang sesuai dengan harapan.

Dalam upaya meningkatkan profesionalisme aparatur di perlukan kemampuan untuk melihat peluang-peluang yang ada bagi pertumbuhan ekonomi, keberanian mengambil resiko dalam memanfaatkan peluang dan kemampuan untuk menggeser alokasi sumber dari kegiatan yang berproduktivitas rendah ke produktivitas yang tinggi merupakan enterpremunial profesionalisme yang dapat terbentuk oleh struktur dan prosedur organisasi yang memberi peluang pada aparat untuk berkreasi dan berinivasi. Selanjutnya harus diikuti oleh kemampuan untuk mengambil keputusan dan langkahlangkah yang perlu dengan mengacu pada misi yang ingin dieapai, bukan semata-mata mengacu pada peraturan yang berlaku (Tjokrowinoto,1996).

Kemampuan profesional lain yang dituntut dari suatu daerah yang bersifat otonom adalah kemampuan untuk mengidentifikasi subyek-subyek yang mempunyai potensi memberikan berbagai input dan sumber bagi proses pembangunan. Di samping itu perlu meningkatkan kemampuan masyarakat untuk tumbuh dan berkembang dengan kekuatan sendiri. Namun demikian yang lebih penting bahwa profesionalisme hanya dapat berkembang kalau ada kehendak politik pemerintah untuk mengubah filsafat birokrasi, tata nilai, serta struktur dan prosedur birokrasi.

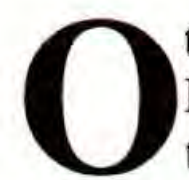

\section{tonomi Daerah Pada Masa Mataram Islam}

Pada masa Kerajaan Mataram Islam telah diterapkan adanya sistim otonomi terhadap beberapa daerah yang berada dibawah kekuasaannya. Sehingga para bupati mempunyai kebebasan dalam mengelola (memerintah) daerahnya masingmasing. Hal ini dapat dilihat sebagai contoh ; bahwa seorang bupati yang berkuasa pada suatu daerah yang mendapat penghasilan dari tanah seluas 160 karya, hal ini bukanlah merupakan penghasilan yang kecil. Belum jika tanah yang diurusi lebih luas lagi. Di Kabupaten Madiun yang pada waktu itu merupakan daerah bawahan dari Kerajaan Mataram Islam yang mempunyai tanah seluas 4000 karya hanya dikepalai oleh seorang bupati. Dengan penghasilan yang cukup ini tidak menutup kemungkinan akan mempunyai pasukan yang kuat dan ada kecenderungan ingin berdiri sendiri lepas dari kekuasaan pusat. Dengan penghasilan yang cukup ini para bupati dapat hidup dengan cukup bahkan sering mewah. Mereka dapat membentuk kehidupan kebupatian dengan susunan tingkatan-tingkatan bawahan yang mencontoh kehidupan kraton (Sucipto, 1980). 
Sifat otonomi ini dapat dilihat dari tidak campur tangan pemerintah pusat, dalam hal swasembada dalam pertanian di setiap daerah. Dengan membiarkan hidup berjalan sekehendaknya, sesuai dengan tradisionalisme konservatif, maka pusat kerajaan menjadi pengawal terhadap gangguan dan baru campur tangan hanya bila terdapat ancaman terhadap ketenangan.

Dengan adanya kekuasaan para bupati yang penuh dan tak terbagi, serta kedudukannya yang otonom menjadikan ia orang yang luas tanggung jawabnya. Karena itu tidak mengherankan bahwa dalam daerahnya dia memegang kekuasaan memerintah, mengadili dan memimpin kontingen pasukan setempat.

Kalau dicerrmati dengan seksama dengan adanya sistem otonomi yang diterapkan oleh Kerajaan Mataram Islam terhadap beberapa daerah bawahannya ini akan mengakibatkan terjadinya disintegrasi. Salah satu akibat diterapkannya otonomi pada suatu daerah pada masa Kerajaan Mataram Islam ini, sering para bupati yang berada dibawah kekuasaannya mempunyai niat untuk memberontak terhadap kekuasaan pusat. Sebuah laporan menyebutkan bahwa bupati-bupati Tuban, Lasem, Brondong, Surabaya dan Pasuruhan. Mereka telah mengadakan persekutuan untuk melawan Kerajaan Mataram Islam ("Remostratie door Balthazar Van Eyndhoven, van de Ghelegenthyt van den Mattaramsche Keyser van Java, ende van de negotie die tot Japara Sonde Cunnen ghedaen warden, Anno 1615", dalam J.K.J.de jonge, De opkomst,IV, hal.58).

Jadi pada masa pemerintahan Kerajaan Mataram Islam, pemerintahan raja sebenarnya merupakan hubungan yang hierarkis antara satuan-satuan kekuasaan yang berdiri sendiri, sangat otonom dan dapat mencukupi kebutuhan sendiri, yang secara vertikal dihubungkan oleh ikatan-ikatan perorangan diantara beberapa pemegang kekuasaan (bupati). Selain dari ikatan-ikatan penghubung berupa pengabdian dan kesetiaan kepada satu orang yang sama, yaitu raja, nampaknya tidak ada hubungan administratif secara horizontal yang dapat memastikan atau melindungi kemerdekaan para bupati dari satu sama lainnya. Dalam kenyataannya tindakan sewenang-wenang terhadap sesama pejabat raja mudah terjadi bila daya pengawasan pemerintah pusat menjadi lemah. Keadaan yang demikian menggoda para pejabat raja (para bupati) untuk bertindak sewenang-wenang terhadap sesamanya, sebab otonomi yang diberikan kepada para pejabat (bupati) itu disertai dengan hak untuk memiliki angkatan bersenjata sendiri (Babad Tanah Jawi, hal.136, 3240.). Oleh sebab itu sangat biasa bila seorang bupati melancarkan pemberontakan, mula-mula mereka menyerang daerahdaerah tetangganya (Ibid). Sebagai contoh Raden Ronggo Prawirodirjo III, bupati Yogyakarta yang termasuk dalam wilayah kekuasaan kepala bupati Madiun kira-kira pada abad XIX, atas prakarsanya sendiri merampas desa-desa di daerah Surakarta yang termasuk dalam wilayah kepala bupati Ponorogo (T.Roorda, Javaansch Brievenboek, Leiden, 1904). Adanya otonomi daerah pada masa pemerintahan 
Kerajaan Mataram Islam ini dapat juga menimbulkan niat para bupati untuk melancarkan pemberontakan terhadap pemerintah pusat, misalnya persekutuan antara bupati Madura, Pangeran Cakraningrat, dengan bupati Surabaya, Tumenggung Jayengrana, pada waktu pemerintahan Amangkurat III (1703-1708) (Babad Tanah Jawi) dalam membantu Pangeran Puger yang kemudian menjadi Paku Buwono I.

Kerajaan Mataram Islam sebagai negara agraris dimana kraton mengandalkan sumbersumber penghasilannya sendiri bagi setiap kebutuhan istana yang bermacam ragam itu dari beberapa daerah yang berada dibawah kekuasaannya. Sumber-sumber itu dapat berupa daerah tertentu yang menyediakan beras untuk keperluan dapur istana, daerah tertentu yang menyediakan minyak kelapa dan hutan tertentu yang menyediakan kayu bagi bangunan istana.

Hal lainnya yang perlu diperhatikan ialah, bahwa bagi negara yang ekonominya didasarkan pada daderah-daerah agraris yang benar-benar otonom dan tata pemerintahannya terdiri atas satuan-satuan yang benar-benar swasembada, maka sebagian besar diambilkan pungutan dari rakyat. Entah dalam bentuk barang ataupun tenaga kerja yang tentunya sangat menguntungkan pihak pemegang kekuasaan (raja). (Soemarsaid Moertono, 1985).

Melihat pentingnya daerah-daerah bawahan yang banyak berperan bagi kelangsungan jalannya pemerintahan, maka bagaimana otonomi yang berlaku pada masing-masing daerah dibawah kekuasaannya dari kerajaan Mataram Islam dapat dilaksanakan tanpa mengakibatkan adanya disintegrasi.

\section{$\mathbf{U}$}

\section{paya Penanggulangan Disintegrasi}

Kerajaan Mataram Islam menerapkan beberapa ketentuan bagi daerah-daerah bawahan yang bersifat otonom dengan beberapa peraturan yang berlaku pada seluruh daerah yang termasuk di bawah kekuasaannya, antara lain; para Bupati harus menghadap ke istana setahun minimal tiga kali yaitu pada waktu diadakan upacara Garebeg Maulud, Garebeg Syawal dan Garebeg Besar. Mereka (para Bupati) mempersembahkan upeti dan pada kesempatan itu raja menunjukkan kebesarannya serta kekuasaannya kepada para bupati, abdi dalem dan para kawula dalem. Cara berikutnya ialah dengan memaksa orang-orang terkemuka yang berpengaruh untuk tinggal di kraton untuk jangka waktu lama, sedangkan daerahnya diurusi oleh wakil mereka masing-masing. Sebagai contoh Pangeran Cakraningrat dari Madura dan Bupati Jayengrana dari Surabaya mereka hampir selalu tinggal di Mataram (Babad Tanah Jawi). Sebelum mereka, Senopati dari Kediri dan kemudian Pangeran Pekik dari Surabaya tinggal juga di Mataram (Ibid). 
Selain mengunakan dua cara tersebut di atas, raja-raja Mataram Islam dalam mempertahankan daerah kekuasaannya sering mengunakan cara-cara kekerasan, bahkan sampai menjatuhkan hukuman mati atas lawan-lawannya beserta keluwarganya. Schrieke mengemukakan bahwa, Panembahan Senopati harus menyingkirkan keluarga penguasa setempat sebelum ia dapat duduk dengan aman di atas tahta kerajaan. Sebagai contoh; keluarga penguasa Pati dan keluarga Adipati Ukur di Jawa Barat dimusnahkan setelah mereka melakukan pemberontakan. Pada masa pemerintahan Sultan Agung juga memusnahkan kaum ningrat daerah Madura, kecuali Sampang (Schrieke Vol II) dan keluarga Sunan Giri dimusnahkan sampai habis sama sekali dengan cara-cara kekerasan.

Untuk mempertahankan daerah-daerah dibawah kekuasaannya yang bersifat otonom, supaya tidak lepas dari kekuasaanya raja-raja Mataram Islam juga mengunakan cara menjalin persekutuan melalui perkawinan. Perkawinan Panembahan Senopati dengan putri Juminah dari Madiun, seorang putri keturunan raja-raja Demak juga perkawinan Sultan Agung dengan putri Panembahan Ratu Cirebon serta perkawinan adik Sultan Ratu Pandan Sari dengan Pangeran Pekik dari Surabaya. Hal semacam ini merupakan contoh perkawinan politik yang dilakukan oleh raja-raja Mataram Islam demi utuhnya daerah-daerah yang berada dibawah kekuasaannya. Adat triman, yaitu raja mengawinkan seorang putri dengan pejabat tinggi penguasa suatu daerah di bawah kekuasaannya juga mempunyai maksud yang sama. Beberapa penulis menganggap kebiasaan priyayi mengambil selir dari kalangan rakyat jelata merupakan upaya untuk mempererat hubungan antara priyayi dengan rakyat.

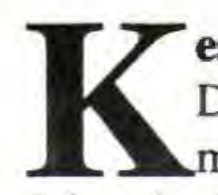

\section{esimpulan}

Dilihat dari kenyataan yang ada bahwa para pejabat daerah (bupati) dalam berbagai segi, maka para pejabat daerah ini harus dipilih dengan seksama, Hal ini dapat kita lihat bahwa dalam pemilihan pegawai maupun pejabat daerah merupakan tugas raja yang sangat penting dan sulit. Hal ini berkaitan dengan sifat para pejabat (bupati) yang akan dipilih harus mempunyai moral yang tinggi, rasa kewajiban yang mendalam dan keberanian besar dan dibutuhkan pejabat (bupati) yang dapat menyelesaikan pekerjaan yang mencakup segala-galanya.

Dapatlah dipahami bahwa satuan-satuan pemerintahan yang demikian ini merupakan bahaya besar bagi kesatuan negara, sebab satuan-satuan (masing-masing daerah) sudah lengkap dan mempunyai kesamaan dalam penataannya dengan pusat kerajaan (Kerajaan Mataram Islam). Pada waktu terdapat perubahan yang menguntungkan dalam hubungan kekuatan mungkin saja dapat mendorong seorang pemimpin daerah yang berani dan ambisius, untuk membebaskan diri dan berusaha merebut kedudukan yang lebih tinggi. 
Oleh sebab itulah raja perlu dengan seksama dan tiada henti-hentinya memperhatikan calon-calon pejabat yang akan menduduki posisi-posisi tertentu baik sebagai pejabat suatu daerah ataupun pejabat dilingkungan istana. Apakah mereka berasal dari darahnya sendiri atau kaum bangsawan setempat di daerah-daerah luar yang tergabung dalam kerajaannya atau orang-orang biasa yang telah naik ke kelas priyayi. Sikap seperti ini tidak bertentangan dengan syarat bahwa raja harus sepenuhnya percaya kepada para pejabatnya, sebab kewaspadaan semacam ini terutama bermaksud untuk menemukan setiap keinginan yang sekecil sekalipun untuk menentang kekuasaannya. Selain beberapa hal yang perlu diperhatikan tersebut di atas seorang raja perlu melakukan pengawasan yang dilakukan secara diam-diam. Seperti kata mata pitaya (mata yang dipercaya) untuk menyelidik rahasia dan lampah sandi untuk mengawasi para bupati-bupati yang berada di bawah kekuasaannya.

\section{KEPUSTAKAAN}

Babad Tanah Jawi, Poestaka (ed.). 1939. Babad Tanah Djawi. Djakarta Vol. 16,21.

Handoko, Hani. 1977. Globalisasi Bisnis dan Strtegi Pengembangan SDM, Seminar Nasional Strategi Meningkatkan Kualitas SDM Indonesia dalam Era Globalisasi, AMP YKPN, Yogyakarta

Rooda, T., 1904. Javaansch Brievenboek, Leiden

Schrieke, B., 1957. Indonesian Sociological Studies, Den Haag, Vol II

Soemarsaid Moertono, 1985. Negara dan Usaha Bina Negara di Jawa Masa Lampau, Studi Tentang Mataram II, Abad XVI sampai XIX. Jakarta, Yayasan Obor Indonesia, Jakarta.

Sucipto, Tjiptoadmojo, 1983. Kota-kota Pantai di Sekitar Selat Madura , Abad XVII sampai Medio Abad XIX, Yogyakarta, UGM.

Tjokrowinoto, Moeljarto., 1996. Pembangunan Delima dan Tantangan, Pustaka Pelajar, Yogyakarta. 